\title{
The problem of malnutrition amongst acutely hospitalized elderly patients
}

\author{
Problem niedożywienia u pacjentów w wieku podeszłym \\ hospitalizowanych w trybie pilnym \\ Edyta Fatyga \\ Department of Internal Medicine, Faculty of Health Sciences in Bytom, \\ Medical University of Silesia, Katowice, Poland
}

\section{ABSTRACT}

INTRODUCTION: The aim of the study was to assess the occurrence of malnutrition in patients who were hospitalized as a matter of urgency in the internal medicine ward, while taking into account the diseases that cause hospitalization. MATERIAL AND METHODS: A cross-sectional observational study was carried out on a sample of 320 elderly persons consecutively admitted to the department of internal medicine from September 2019 to January 2020. The nutritional status was measured by: a Subjective Global Assessment (SGA) questionnaire followed by anthropometric measurement (body mass and height) as well as the body mass index (BMI) and body composition analysis using the electric bioimpedance (BI) method.

RESULTS: The studies showed malnutrition in $42.6 \%$ of men and in $44.7 \%$ of women, and severely malnutrition in $24 \%$ of men and $24.1 \%$ of women. Malnutrition was most often found in patients with chronic obstructive pulmonary disease (COPD) and urinary tract infections, and severe malnutrition in patients with cardiovascular diseases.

CONCLUSIONS: High rates of malnutrition and severe malnutrition occur in elderly patients urgently hospitalized due to internal diseases. SGA and BI are useful tools for controlling the nutritional status in this group of patients.

KEY WORDS

malnutrition, geriatrics, hospitalization, Subjective Global Assessment, body mass index, electric bioimpedance 


\section{STRESZCZENIE}

WSTĘP: Celem pracy była ocena niedożywienia u pacjentów hospitalizowanych $\mathrm{w}$ trybie pilnym na oddziale internistycznym z uwzględnieniem chorób będących przyczyną hospitalizacji.

MATERIAL I METODY: Przekrojowe badanie obserwacyjne przeprowadzono na próbie 320 osób w wieku podeszłym przyjmowanych kolejno na oddział chorób wewnętrznych od września 2019 r. do stycznia 2020 r. Stan odżywienia sprawdzano za pomocą: kwestionariusza Subiektywnej Globalnej Oceny (SGA), pomiaru antropometrycznego (masa ciała i wzrost), wskaźnika masy ciała (BMI) oraz analizy składu ciała za pomocą bioimpedancji elektrycznej (BI).

WYNIKI: Badania wykazały niedożywienie u 42,6\% mężczyzn i 44,7\% kobiet oraz poważne niedożywienie u $24 \%$ mężczyzn i 24,1\% kobiet. Niedożywienie stwierdzano najczęściej u osób z przewlekłą obturacyjną chorobą płuc (POChP) i z zakażeniami układu moczowego, a poważne niedożywienie u osób z chorobami układu krążenia.

WNIOSKI: U pacjentów w wieku podeszłym hospitalizowanych w trybie pilnym z powodu chorób wewnętrznych występuje wysoki wskaźnik niedożywienia i poważnego niedożywienia. SGA i BI są przydatnymi narzędziami do kontroli stanu odżywienia w tej grupie chorych.

\section{SŁOWA KLUCZOWE}

niedożywienie, geriatria, hospitalizacja, Subiektywna Globalna Ocena, wskaźnik masy ciała, bioimpedancja elektryczna

\section{INTRODUCTION}

Proper nutrition is one of the most important factors influencing the health of the elderly. Nutritional disorders, including malnutrition, are a serious medical, psychological and social problem. The prevalence of malnutrition is significant in old age. In Europe and North America, malnutrition affects from 1 to $15 \%$ of elderly people living in their own homes, but from 25 to $60 \%$ in the case of elderly people in geriatric care facilities, reaching $35-65 \%$ of elderly people in hospitals [1]. As shown, in the representative population of PolSenior, it concerns as much as $7.5 \%$ of people aged 65 and up [2]. It is almost twice as common in women as in men, but the risk also increases with age. In addition, the following factors are of importance when considering the increased risk of malnutrition in Poland: living in the countryside, living without a life partner and living in a (declared) poor financial situation. When considering the dangers of malnutrition, special attention should be paid to age as a risk factor because according to the prognoses for Poland, the 60-64 age group will only slightly increase, while the 80 and up age group will more than double by 2050 [3].

In order to standardize the criteria and create the possibility of conducting analyses on malnutrition in various regions of the world, the Global Leadership Initiative on Malnutrition (GLIM) initiative was published at the beginning of 2019 [4,5]. The criteria are defined as two-step: the first stage is screening of malnutrition, and the second stage - proper diagnostics completed with an analysis of the severity of malnutrition.

For the screening tests, GLIM experts did not explicitly recommend a specific tool, but indicated the possibility of using any that have been validated for this purpose, e.g. Nutritional Risk Score-2002 (NRS-2002), Subjective Global Assessment (SGA), Mini Nutritional Assessment (MNA) or the MNA-short version.
According to Polish legislation, all hospitalized persons are to be screened (with the exception of patients in the emergency department) - in the case of adults, using NRS-2002 or SGA [6].

Nutritional disorders occurring in the elderly over 65 are most often the result of changes in the body during the aging process, social and economic conditions, and the occurrence of diseases [7].

The most important factor in malnutrition is chronic diseases, as well as their related therapeutic treatments. Malnutrition is observed in people suffering from diseases of the cardiovascular, respiratory and neurological systems, mental disorders (especially depression and dementia), cancer, acute and chronic infections, gastrointestinal diseases, and diseases of the endocrine system [8].

Untreated and unrecognized malnutrition may cause: deteriorated efficiency of organs and systems, atrophy of intestinal villi (digestive and absorption disorders), weakening of intestinal peristalsis, a decrease in protein synthesis, in particular albumin, the occurrence of hypochromic anaemia (a reduced supply of vitamin B12 and iron), weight loss and a decrease in muscle strength (sarcopenia) $[9,10]$. In the case of exacerbation of a chronic disease, concomitant malnutrition may be an additional factor hindering the stabilization of the disease process and requiring hospitalization $[11,12]$ Thus, the aim of the study was to assess the occurrence of malnutrition in patients who were hospitalized as a matter of urgency in the internal medicine ward, while taking into account the diseases that cause hospitalization.

\section{MATERIAL AND METHODS}

\section{Ethics}

The current study was conducted in accordance with the Declaration of Helsinki. The project was approved by the Bioethics Committee of the Medical University 
of Silesia in Katowice - decision No KNW/0022/KB1/28/18 of April 17, 2018. The participants were informed in detail about the study and gave their written consent. Participation in the study was voluntary and informed.

\section{Patients}

The cross-sectional observational study was carried out on a sample of 320 elderly persons consecutively admitted to the department of internal medicine from September 2019 to January 2020. The patients were qualified according to the order of reporting, who had indications for admission to the Department of Internal Medicine, Medical University of Silesia in Katowice. The exclusion criteria from the study were as follows: non-Polish speaking, transferred from another hospital, alcoholism, severe dementia/confusion, terminal stage of chronic diseases, with advanced cancer, noncooperative/refused, alcohol/drug addicted, implanted pacemaker, endoprosthesis, metal implants, as well as generalized chronic body oedema.

\section{Methods}

The nutritional status of each senior was assessed on the second or third day of their stay, always in the morning. In Poland, in accordance with the regulation of the Minister of Health, September 15, 2011 (amendment on November 22, 2013), one of the two scales: NRS-2002 or SGA is the recommended tool for the routine assessment of the nutritional status of hospitalized patients.

The study used the translated version of the SGA questionnaire followed by anthropometric measuring of body weight and height as well as the body mass index (BMI) and body composition analysis using the electric bioimpedance (BI) method.

The 7-point SGA scale consisted of 2 categories: medical history and physical examination. The medical history section includes weight change, dietary intake, gastrointestinal symptoms, functional capacity, in addition to disease and comorbidity data. The physical examination section includes the loss of subcutaneous fat, muscle wasting, and oedema. The trained investigators rated each item from 1 to 7 , and decided on the overall SGA score. Based on the overall SGA score, the patients were categorized into 3 groups as SGA A (SGA score 6-7, well nourished - WN), B (SGA score 3-5, mildly to moderately malnourished - MN), or C (SGA score 1-2, severely MN) [13].

Body height was measured to the nearest $0.1 \mathrm{~cm}$ using a non-metallic and non-stretchable tape. The weight and body composition analysis were determined by bioelectrical BI using the Tanita MC-780 multi-frequency segmental Body Composition Analyzer (Tanita Corporation, Tokyo). The MC-780 uses the latest multi-frequency technology to record a comprehensive range of measurements in just
20 seconds, from segmental fat levels, phase angle and intra/extra cellular body water [12]. BMI was calculated as weight $/ \mathrm{height}^{2}\left(\mathrm{~kg} / \mathrm{m}^{2}\right)$.

\section{Statistical analysis}

The results were statistically analysed using the Statistica 13.1 program. The obtained results were based on an MS Excel spreadsheet and presented in the form of tables. In the statistical analysis, the significance level was $\mathrm{p}<0.05$ and the following were used: descriptive statistics, multi-way tables and Pearson's Chi-squared test of independence.

\section{RESULTS}

In the end, the study involved 320 geriatric patients (170 women and 150 men) hospitalized in the Department of Internal Medicine. The mean age of the entire cohort was $75 \pm 5.2$ years. The characterization of the group for morbidity is shown in Table I.

Table I. Most frequent causes of acute hospitalization and associated disorders in elderly

Tabela I. Najczestsze przyczyny nagłej hospitalizacji i zwiazanych z nia zaburzeń u osób starszych

\begin{tabular}{lc}
\hline \multicolumn{1}{c}{ Causes of hospitalization } \\
\hline \multicolumn{1}{c}{ Disease } & Frequency (\%) \\
\hline Cardiac insufficiency & 36 \\
COPD & 22 \\
DMt2 & 17 \\
Infection of pulmonary or urinary tract & 15 \\
Gastritis with duodenitis & Associated disorders \\
& 10 \\
Electrolyte disturbances & \\
Arterial hypertension & 43 \\
Secondary anemia & 31 \\
Renal failure & 15
\end{tabular}

COPD - chronic obstructive pulmonary disease, DMt2 - type 2 diabetes mellitus decompensated

\section{Nutritional assessment}

The following results were obtained from the Subjective Global Nutritional Assessment. Changes in body weight were analysed in the last 2 weeks prior to hospitalization. No change in body weight was confirmed by $88 \%$ of the respondents, while in $12 \%$ of the cases the body weight had decreased. Changes in food intake compared to previous nutrition were declared by $9 \%$ of the respondents, a statistically significant greater number of patients did not introduce changes in food intake (91\%) and followed a diet similar to the optimal diet based on solid foods (an easily digestible diet). A complete liquid diet was used by $2 \%$ of the respondents, and a soft foods diet by $2 \%$ of the respondents. 
The occurrence of gastrointestinal symptoms (lasting for more than 2 weeks) applied to a smaller group of subjects (29\%), while $71 \%$ of subjects did not experience any symptoms. In the group of people who experienced gastrointestinal symptoms, $14 \%$ of respondents reported constipation, $7 \%$ acid reflux, $6 \%$ lack of appetite, and $2 \%$ nausea.

Limitations in both physical activity and independence was noted in $24 \%$ of the respondents, while $76 \%$ of the patients did not experience changes in their physical capacity. Finally, the analysis of the subjective global nutritional status assessment results allowed the advancement of changes to be determined in the group of hospitalized patients in the internal medicine ward. The well-nourished status (SGA A) was present in 50 men $(33.33 \%)$ and in 53 women $(31.2 \%), 64$ men $(42.6 \%)$ and 76 women $(44.7 \%)$ were moderately or suspected of being malnourished (SGA B) and severe malnutrition (SGA C) was found in 36 men (24\%) and 41 women $(24.1 \%)$.

The greatest undernourishment was found in patients with chronic obstructive pulmonary disease (COPD) and urinary tract infections and malnutrition was found in the highest ratio in patients with cardiovascular diseases (Table II).

Table II. Nutritional status assessed by SGA method depending on reason for acute hospitalization

Tabela II. Stan odżywienia oceniany za pomocą kwestionariusza SGA w zależności od przyczyny nagłej hospitalizacji

\begin{tabular}{lcccccc}
\hline & \multicolumn{6}{c}{ Nutritional status group } \\
\cline { 2 - 7 } \multicolumn{1}{c}{ Type of disease } & \multicolumn{2}{c}{ SGA A } & \multicolumn{3}{c}{ SGA B } & \multicolumn{2}{c}{ SGA C } \\
\cline { 2 - 7 } & $\begin{array}{c}\text { M } \\
(\%)\end{array}$ & $\begin{array}{c}\text { F } \\
(\%)\end{array}$ & $\begin{array}{c}\text { M } \\
(\%)\end{array}$ & $\begin{array}{c}\text { F } \\
(\%)\end{array}$ & $\begin{array}{c}\text { M } \\
(\%)\end{array}$ & $\begin{array}{c}\text { F } \\
(\%)\end{array}$ \\
\hline Cardiovascular disease & 7.7 & 18.6 & 38.5 & 27.1 & 53.8 & 54.3 \\
COPD & 33.3 & 42.3 & 66.7 & 57.7 & - & - \\
Pneumonia & 37.5 & 52.9 & 62.5 & 47.1 & - & - \\
DMt2 & 18.2 & 20 & 45.5 & 46.7 & 36.3 & 33.3 \\
Urinary tract infection & - & 28.6 & 100 & 57.1 & - & 14.3 \\
Gastrointestinal diseases & - & 44.4 & 100 & 55.6 & - & - \\
\hline
\end{tabular}

COPD - chronic obstructive pulmonary disease, DMt2 - type 2 diabetes mellitus decompensated, $\mathrm{M}$ - male, $\mathrm{F}$ - female

\section{Analysis of body composition using BI method}

The analysis of body composition of the patients using BI method depending on the causes of hospitalization is illustrated in Table III.

In the patients with cardiovascular diseases, a normal BMI value was found in $83.3 \%$ of men and $79.35 \%$ of women. On the other hand, an incorrect value of BMI occurred in $16.7 \%$ of men and $20.6 \%$ of women $(\mathrm{p}=0.00)$. Adipose tissue at a normal level was present in $25 \%$ of men and $51.1 \%$ of women, higher adipose tissue indicating: overweight in $63.9 \%$ of men and $39.1 \%$ of women, and obesity in $11.1 \%$ of men and $9.8 \%$ of women $(\mathrm{p}=0.089)$. A proper water content in the body was found in $30.8 \%$ of men and $25.4 \%$ of women; the water content was found to be either above or below the norm in $69.2 \%$ of men and $74.6 \%$ of women ( $\mathrm{p}=0.707)$.

In the patients with COPD, a normal BMI value was found in $60 \%$ of men and $56 \%$ of women, an incorrect BMI value for men $40 \%$, and $44 \%$ for women $(\mathrm{p}=0.000)$. A normal level of adipose tissue was present in $17.5 \%$ of men and $40 \%$ of women, higher adipose tissue indicating: overweight in $52.5 \%$ of men and $30.4 \%$ of women, obesity in $30 \%$ of men and $29.6 \%$ of women $(\mathrm{p}=0.012)$. A proper water content in the body was found in $50 \%$ and $38.4 \%$ of women; the water content was found to be either above or below the norm in $50 \%$ of men and $61.6 \%$ of women $(\mathrm{p}=0.01)$.

In the patients hospitalized due to pneumonia, a normal BMI value was found in all the men and in $94.1 \%$ of women, and an incorrect BMI value for women in $5.9 \%$ $(\mathrm{p}=0.001)$. A normal level of adipose tissue was present in $37.5 \%$ of men and $64.7 \%$ of women, higher adipose tissue indicating: overweight in $62.5 \%$ of men and $29.4 \%$ of women, obesity in $5.9 \%$ of women ( $\mathrm{p}=0.437$ ). A normal water content in the body was found in $37.5 \%$ of men and $35.3 \%$ of women, while a water content that was either above or below the norm was found in $62.5 \%$ of men and $64.7 \%$ of women $(\mathrm{p}=0.021)$.

In diabetic patients, a normal BMI value was found in $45.5 \%$ of men and $60 \%$ of women, an incorrect BMI value for men was $54.5 \%$ and for women $40 \%$ ( $p=0.635$ ). A normal level of adipose tissue was found in $18.2 \%$ of men and $36.7 \%$ of women, higher adipose tissue indicating: overweight in $45.5 \%$ of men and $40 \%$ of women, obesity in $36.3 \%$ of men and $29.6 \%$ of women $(p=0.261)$. A proper water content in the body was found in $50 \%$ of men and $38.4 \%$ of women, with an incorrect water content in $50 \%$ of men and $23.3 \%$ of women $(\mathrm{p}=0.194)$.

In the patients with urinary tract infections, a normal BMI value was found in all the men and in $85.7 \%$ of women, and an incorrect BMI value for women was $14.3 \%(p=0.003)$. A normal level of adipose tissue was present in $28.6 \%$ of women, higher adipose tissue indicating: overweight in all the men and in $57.1 \%$ of women, obesity was found in $14.3 \%$ of women $(p=0.386)$. A normal water content in the body was found in $57.1 \%$ of women, with an abnormal water content in all the men and in $42.9 \%$ of women $(\mathrm{p}=0.552)$. 
Table III. Analysis of body composition of elderly using electric bioimpedance method depending on causes of hospitalization Tabela III. Analiza składu ciała osób starszych za pomoca bioimpedancji elektrycznej w zależności od przyczyn hospitalizacji

\begin{tabular}{|c|c|c|c|c|c|c|c|c|c|c|c|}
\hline & & \multicolumn{2}{|c|}{ Level of BMI } & \multirow[b]{2}{*}{$p$} & \multicolumn{3}{|c|}{ Level of adipose tissue } & \multirow[b]{2}{*}{$p$} & \multicolumn{2}{|c|}{ Water body content } & \multirow[b]{2}{*}{$\mathbf{P}$} \\
\hline & & $\begin{array}{l}\text { within norm } \\
(\%)\end{array}$ & $\begin{array}{c}\text { outside of the } \\
\text { norm (\%) }\end{array}$ & & $\begin{array}{c}\text { within norm } \\
(\%)\end{array}$ & $\begin{array}{l}\text { overweight } \\
(\%)\end{array}$ & $\begin{array}{c}\text { obese } \\
(\%)\end{array}$ & & $\begin{array}{c}\text { correct } \\
(\%)\end{array}$ & $\begin{array}{c}\text { incorrect } \\
(\%)\end{array}$ & \\
\hline \multirow{2}{*}{$\begin{array}{l}\text { Cardiovascular } \\
\text { disease }\end{array}$} & M & 83.3 & 16.7 & \multirow{2}{*}{0.000} & 25 & 63.9 & 11.1 & \multirow{2}{*}{0.089} & 30.8 & 69.2 & \multirow{2}{*}{0.707} \\
\hline & $\mathrm{F}$ & 79.35 & 20.6 & & 51.1 & 39.1 & 9.8 & & 25.4 & 74.6 & \\
\hline \multirow{2}{*}{ COPD } & M & 60 & 40 & \multirow{2}{*}{0.000} & 17.5 & 52.5 & 30 & \multirow{2}{*}{0.012} & 50 & 50 & \multirow{2}{*}{0.010} \\
\hline & $\mathrm{F}$ & 56 & 44 & & 40 & 30.4 & 29.6 & & 38.4 & 61.6 & \\
\hline \multirow{2}{*}{ Pneumonia } & M & 100 & - & \multirow{2}{*}{0.001} & 37.5 & 62.5 & - & \multirow{2}{*}{0.437} & 37.5 & 62.5 & \multirow{2}{*}{0.021} \\
\hline & $\mathrm{F}$ & 94.1 & 5.9 & & 64.7 & 29.4 & 5.9 & & 35.3 & 64.7 & \\
\hline \multirow{2}{*}{ DMt2 } & M & 45.5 & 54.5 & \multirow{2}{*}{0.635} & 18.2 & 45.5 & 36.3 & \multirow{2}{*}{0.261} & 45.5 & 54.5 & \multirow{2}{*}{0.194} \\
\hline & $\mathrm{F}$ & 60 & 40 & & 36.7 & 40 & 23.3 & & 63.3 & 36.7 & \\
\hline \multirow{2}{*}{$\begin{array}{l}\text { Urinary tract } \\
\text { infection }\end{array}$} & M & 100 & - & \multirow{2}{*}{0.003} & - & 100 & - & \multirow{2}{*}{0.386} & - & 100 & \multirow{2}{*}{0.0552} \\
\hline & $\mathrm{F}$ & 85.7 & 14.3 & & 28.6 & 57.1 & 14.3 & & 57.1 & 42.9 & \\
\hline \multirow{2}{*}{$\begin{array}{l}\text { Gastrointestinal } \\
\text { diseases }\end{array}$} & $M$ & 100 & - & \multirow{2}{*}{0.053} & - & 100 & - & \multirow{2}{*}{0.302} & - & 100 & \multirow{2}{*}{0.314} \\
\hline & $\mathrm{F}$ & 77.8 & 22.2 & & 66.7 & 33.3 & - & & 66.7 & 33.3 & \\
\hline
\end{tabular}

COPD - chronic obstructive pulmonary disease, DMt2 - type 2 diabetes mellitus decompensated, $M$ - male, $\mathrm{F}$ - female

\section{DISCUSSION}

Assessing nutritional status is a very important aspect of treating elderly patients. Due to the complexity of malnutrition in the elderly and the unreliability of individual indicators of nutritional status, for the best methods are still being sought for assessing the risk of malnutrition, especially in this demographic.

A tool which enables the diagnosis of malnutrition is BMI, the abnormal range below the range of $23.5 \mathrm{~kg} / \mathrm{m}^{2}$ for women in the current study was $60.49 \%$, and for men $84.21 \%$, which indicates the risk of malnutrition. In the screening of the independently-living elderly population, an abnormal range of BMI was present in $72 \%$ of the respondents, while in the study by Charzewska et al. [14] a range of BMI over $30 \mathrm{~kg} / \mathrm{m}^{2}$ was found in $44 \%$ of the respondents. Similar results were obtained in a study on the evaluation of selected anthropometric and biochemical parameters in a group of women over 60 , where excessive body weight was found in $87.5 \%$ of the respondents [15]. Among the group of elderly people studied by Ptasińska et al. [16], the range of abnormal body mass index was found in $70.3 \%$ of the participants, and in the study by Cierzniakowska et al. [17] the range of overweight and obese participants over 70 years of age was $45.8 \%$. In the study conducted by Pawlińska-Chmara [18] on a group of Polish centenarian women, the percentage overweight or obesity was $22.1 \%$ of the respondents. Additionally, in the study of the relationship between the self-esteem of women over 60 and their body shape, posture and physical activity, obesity was present in $27 \%$ studied women [19]. In a study by Shah and
Braverman [20] a BMI over $30 \mathrm{~kg} / \mathrm{m}^{2}$ was present in $24 \%$ of men and $26 \%$ of women.

In the present study based on the SGA scale, a well-nourished status (SGA A) was present in 50 men $(33.33 \%)$ and in 53 women (31.2\%), 64 men (42.6\%) and 76 women $(44.7 \%)$ were moderately or suspected of being malnourished (SGA B) and severe malnutrition (SGA C) was found in 36 men (24\%) and 41 women $(24.1 \%)$. According to Sun et al. [21] the suspicion of malnutrition was found in $40 \%$ of hospitalized patients. Similar results were obtained by van Bokhorst-de van der Schueren et al. [22]. In a study conducted by Dutch researchers, the risk of malnutrition among outpatients was $58 \%$, compared to Malaysia where every third person is diagnosed as severely malnourished [23], while Abd Aziz et al. [24] found that every second person is malnourished in that country. Koczy et al. [25] suggested that the phenomenon of malnutrition occurs in $16 \%$ of elderly residing in 24-hour care centres, and $58 \%$ of residents are at risk of malnutrition. In institutionalized older adults, malnutrition was diagnosed in $26.2 \%$ of the respondents [26]. Bartosiak et al. [27] shows that more frequent hospitalization (more than 5 times a year) is associated with a higher percentage of malnourished patients $-35.71 \%$ of patients. Malnutrition among the elderly is associated with a longer hospitalization period, as indicated by the studies conducted by O'Shea et al. [28], while the study of Australians shows that diagnosed malnutrition results in prolonged hospital stays in order to implement appropriate treatment [29]. In Asia, malnutrition is found in up to $78 \%$ of hospitalized patients [30].

In our study of the body composition analysis, the average body fat content among the surveyed women 
was $37.37 \%$, and for the surveyed men $28.89 \%$, which indicates overweight. According to the study by Adamska et al. [31] on the differences in eating habits and preferences of adults depending on age, the percentage of adipose tissue in the studied group of men indicated overweight; their adipose tissue ranged within $27 \%$, and for women $35 \%$, which was indicated by the correct range of the norm. Abdominal obesity was present in $41 \%$ of Spanish respondents, which was associated with an increased content of adipose tissue [32]. Several scientific publications also showed numerous abnormalities in the percentage of adipose tissue in the group of men and women [33,34,35]. Kim et al. [10] suggested that the increased level of adipose tissue in the elderly in Korea is associated with a decrease in muscle mass, which affects the development of sarcopenia. Korean researchers conducted a study assessing body composition and observed how a properly balanced diet positively affects the slower process of muscle mass loss.

Elderly persons are the highest risk for developing malnutrition and dehydration. Water content decreases with age. Based on the results of the body composition analysis obtained with the Tanita analyser, the water content in the body should be between $45-60 \%$ for women and $50-65 \%$ for men. In our study, the mean body water content for women was $44.17 \%$ and for men 49.55, which indicates an abnormal water content in the body. The mean body water content among Japanese respondents was $53.1 \%$ [36], while in the Jasiński et al. [37] study, the mean body water content in non-exercising women over 50 was $47.5 \%$. Water imbalance and under-nutrition are preventable disorders and the early identification of such conditions may improve seniors' quality of life, and reduce disease burden [12]. The assessment of malnutrition and hydration status by the SGA questionnaire and the Tanita BI system is relatively quick, easy and are non-invasive methods $[38,39,40,41,42,43]$.

\section{CONCLUSIONS}

The assessment of the nutritional status of elderly hospitalized in the Department of Internal Diseases showed abnormalities in terms of malnutrition. The study used a subjective global assessment of nutritional status, which is one of the screening tests recommended by the European Society for Parenteral and Enteral Nutrition (ESPEN) and is a commonly used tool.

The assessment of nutritional status is an important element in determining the risk of malnutrition due to the health consequences for the elderly. Early diagnosis can improve treatment outcomes for comorbid conditions. The priority is to develop a uniform, interdisciplinary strategy for the assessment of nutritional status in elderly people. It should be remembered that the method of nutritional assessment used is of less significance than the actual detection of malnutrition and further implementation of nutritional management.

As the highest undernourishment was found in patients with COPD and urinary tract infections and malnutrition was found in the highest ratio in patients with cardiovascular diseases, we suggest controlling the nutritional status with an easy tool like SGA or BI in such diseased persons even in urgent

\section{REFERENCES}

1. Gil-Montoya J.A., Ponce G., Sánchez L.I., Barrios R., Llodra J.C., Bravo M. Association of the oral health impact profile with malnutrition risk in Spanish elders. Arch. Gerontol. Geriatr. 2013; 57(3): 398-402, doi: 10.1016/j.archger.2013.05.002.

2. Krzymińska-Siemaszko R., Mossakowska M., Skalska A., Klich-Rączka A., Tobis S., Szybalska A. et al. Social and economic correlates of malnutrition in Polish elderly population: the results of PolSenior study. J. Nutr. Health Aging 2015; 19(4): 397-402, doi: 10.1007/s12603-014-0572-7.

3. http://www.senior.gov.pl [Accessed: 25 May 2020]

4. Jensen G.L., Cederholm T., Correia M.I., Gonzalez M.C., Fukushima R., Higashiguchi $\mathrm{T}$. et al. GLIM criteria for the diagnosis of malnutrition: a consensus report from the global clinical nutrition community. J. Parenter. Enteral Nutr. 2019; 43(1): 32-40, doi: 10.1002/jpen.1440.

5. Sánchez-Rodríguez D., Annweiler C., Cederholm T. A translationa approach for the clinical application of recently updated definitions of malnutrition (GLIM) and sarcopenia (EWGSOP2). Maturitas 2019; 122: 89-90, doi: 10.1016/j.maturitas.2018.11.013.

6. Rozporządzenie Ministra Zdrowia z dnia 22 listopada 2013 r. w sprawie świadczeń gwarantowanych z zakresu leczenia szpitalnego. ISAP - Internetowy System Aktów Prawnych,

http://prawo.sejm.gov.pl/isap.nsf/DocDetails.xsp?id=WDU20130001520 [Accessed: 5 January 2020].

7. Zhang Z.Q., He L.P, Xie X.Y., Ling W.H., Deng J., Su Y.X., Chen Y.M. Association of simple anthropometric indices and body fat with early atherosclerosis and lipid profiles in Chinese adults. PLoS One 2014; 9(8): e104361, doi: 10.1371 /journal pone 0104361 .

8. Hengeveld L.M., Wijnhoven H.A., Olthof M.R., Brouwer I.A., Harris T.B., Kritchevsky S.B. et al. Prospective associations of poor diet quality with long-term incidence of protein-energy malnutrition in community-dwelling older adults: the Health, Aging, and Body Composition (Health ABC) Study. Am. J. Clin. Nutr. 2018; 107(2): 155-164, doi: 10.1093/ajcn/nqx020.

9. Kim T.N., Park M.S., Kim Y.J., Lee E.J., Kim M.K., Kim J.M. et al. Association of low muscle mass and combined low muscle mass and visceral obesity with low cardiorespiratory fitness. PLoS One 2014: 9(6): e100118, doi: 10.1371/journal.pone.0100118.

10. Kim J., Lee Y., Kye S., Chung Y.S., Kim K.M. Association between healthy diet and exercise and greater muscle mass in older adults. J. Am. Geriatr. Soc. 2015; 63(5): 886-892, doi: 10.1111/jgs.13386.

11. Wyka J., Biernat J., Mikołajczak J., Piotrowska E. Assessment of dietary intake and nutritional status (MNA) in Polish free-living elderly people from rural environments. Arch. Gerontol. Geriatr. 2012: 54(1): 44-49, doi: 10.1016/j.archger.2011.02.001.

12. Malczyk E., Dzięgielewska-Gęsiak S., Fatyga E., Ziółko E., Kokot T., Muc-Wierzgon M. Body composition in healthy older persons: role of the ratio of extracellular/total body water. J. Biol. Regul. Homeost. Agents 2016; 30(3): $767-772$.

13. Kwon Y.E., Kee Y.K., Yoon C.Y., Han I.M., Han S.G., Park K.S. et al. Change of Nutritional Status Assessed Using Subjective Global Assessment Is Associated With All-Cause Mortality in Incident Dialysis Patients. Medicine 2016; 95(7): e2714, doi: 10.1097/MD.0000000000002714.

14. Charzewska J., Chwojnowska Z., Chabros E., Wajszczyk B., Bułhak-Jachymczyk B. Energy and nutrient intake versus nutrition status of elderly women. Post. Nauk Med. 2011; 24(9): 732-738.

15. Brończyk-Puzoń A., Piecha D., Nowak J., Koszowska A., Kulik-Kupka K., Dittfeld A., Zubelewicz-Szkodzińska B. Guidelines for dietary 
management of menopausal women with simple obesity. Prz. Menopauzalny 2015; 14(1): 48-52, doi: 10.5114/pm.2015.48678

16. Ptasińska O., Białecka A., Stelmaszczyk-Kusz A. Opinions on needs for dietary advices in elderly people. [Article in Polish]. Geriatria 2014; 8: 150-157 .

17. Cierzniakowska K., Szewczyk M.T., Kozłowska E., Banaszkiewicz Z. Popow A., Mościcka P. et al. Nutrition state assessment of elder patient hospitalised in a surgical ward. [Article in Polish]. Pielęg. Chir. Angiol. 2017; 11(2): 61-67.

18. Pawlińska-Chmara R. Characteristics of the somatic and nutritional status of polish centenarian women. [Article in Polish]. Pomeranian J. Life Sci. 2015; 61(2): $180-185$.

19. Gawlik K., Moczek K., Celebańska D. Correlations of self-esteem in women aged over 60 with body build, body posture and physical activity. [Article in Polish]. Gerontol. Pol. 2017; 25: 34-38.

20. Shah N.R., Braverman E.R. Measuring adiposity in patients: the utility of body mass index (BMI), percent body fat, and leptin. PLoS One 2012; 7(4):e33308, doi: 10.1371/journal.pone.0033308

21. Sun H., Zhang L., Zhang P., Yu J., Kang W., Guo S. et al. A comprehensive nutritional survey of hospitalized patients: Results from nutritionDay 2016 in China. PLoS One 2018; 13(3): e0194312, doi 10.1371/journal.pone.0194312.

22. van Bokhorst-de van der Schueren M.A., Lonterman-Monasch S., de Vries O.J., Danner S.A., Kramer M.H., Muller M. Prevalence and determinant for malnutrition in geriatric outpatients. Clin. Nutr. 2013; 32(6): 1007-1011, doi: 10.1016/j.clnu.2013.05.007.

23. Wei K., Nyunt M.S., Gao Q., Wee S.L., Ng T.P. Frailty and Malnutrition: Related and Distinct Syndrome Prevalence and Association among Community-Dwelling Older Adults: Singapore Longitudinal Ageing Studies. J. Am. Med. Dir. Assoc. 2017; 18(12): 1019-1028, doi: 10.1016/j.jamda.2017.06.017. 24. Abd Aziz N.A.S., Teng N.I.M.F., Abdul Hamid M.R., Ismail N.H. Assessing the nutritional status of hospitalized elderly. Clin. Interv. Aging 2017; 12: 1615-1625, doi: 10.2147/CIA.S140859.

25. Koczy M., Irzyniec T., Nowak-Kapusta Z. The nutritional condition of the elderly people staying in 24 hours a day care centres. [Article in Polish]. Gerontol. Pol. 2019; 27: 36-42.

26. Marques M., Faria A., Cebola M. Body mass index and body composition in institutionalized older adults with malnutrition, sarcopenia and frailty. Eur J. Public Health 2019; 29(Suppl 1): 23-24

27. Bartosiak E., Maier K., Świątoniowska N.A., Jankowska-Polańska B. Factors influencing nutritional status of patients treated due to aplastic and iron deficiency anemia. [Article in Polish]. Palliat. Med. Pract. 2019; 13(1): 1-10, doi: 10.5603/PMPI.2019.0001

28. O' Shea E., Trawley S., Manning E., Barrett A., Browne V., Timmons S Malnutrition in hospitalised older adults: a multicentre observational study of prevalence, associations and outcomes. J. Nutr. Health Aging 2017; 21(7): 830-836, doi: 10.1007/s12603-016-0831-x.

29. Marshall S., Young A., Bauer J., Isenring E. Malnutrition in Geriatric Rehabilitation: Prevalence, Patient Outcomes, and Criterion Validity of the Scored Patient-Generated Subjective Global Assessment and the Min Nutritional Assessment. J. Acad. Nutr. Diet. 2016; 116(5): 785-794, doi 10.1016/j.jand.2015.06.013.

30. Chern C.J., Lee S.D. Malnutrition in hospitalized Asian seniors: an issue that calls for action. J. Clin. Gerontol. Geriatr. 2015; 6(3): 73-77, doi 10.1016/j.jcgg.2015.02.007.
31. Adamska E., Ostrowska L., Adamska E., Maliszewska K., Citko A., Waszczeniuk M. et al. Differences in dietary habits and food preferences of adults depending on the age. [Article in Polish]. Rocz. Panstw. Zakl. Hig. 2012; 63(1): 73-81.

32. Bibiloni M.D.M., Karam J., Bouzas C., Aparicio-Ugarriza R., Pedrero-Chamizo R., Sureda A. et al Association between Physical Condition and Body Composition, Nutrient Intake, Sociodemographic Characteristics, and Lifestyle Habits in Older Spanish Adults. Nutrients 2018; 10(11): 1608, doi: 10.3390/nu10111608.

33. Scafoglieri A., Clarys J.P., Bauer J.M., Verlaan S., Van Malderen L., Vantieghem S. et al. Predicting appendicular lean and fat mass with bioelectrical impedance analysis in older adults with physical function decline - The PROVIDE study. Clin. Nutr. 2017; 36(3): 869-875, doi: 10.1016/j.clnu.2016.04.026

34. Koster A., Stenholm S., Alley D.E., Kim L.J., Simonsick E.M., Kanaya A.M. et al. Body fat distribution and inflammation among obese older adults with and without metabolic syndrome. Obesity 2010; 18(22): 2354-2361, doi: 10.1038/oby.2010.86.

35. Mundi M.S., Karpyak M.V., Koutsari C., Votruba S.B., O'Brien P.C., Jensen M.D. Body fat distribution, adipocyte size, and metabolic characteristics of nondiabetic adults. J. Clin. Endocrinol. Metab. 2010; 95(1): 67-73, doi: $10.1210 /$ jc. $2009-1353$

36. Iizuka Y., Iizuka H., Mieda T., Tsuyoshi T., Yamamoto A., Ohsawa T. et al. Association between neck and shoulder pain, back pain, low back pain and body composition parameters among the Japanese general population. BMC Musculoskelet. Disord. 2015; 16: 333, doi: 10.1186/s12891-015-0759-z.

37. Jasiński R., Socha M., Sitko L., Kubicka K., Woźniewski M., Sobiech K.A. Effect of nordic walking and water aerobics training on body composition and the blood flow in lower extremities in elderly women. J. Hum. Kinet. 2015; 45: 113-122, doi: 10.1515/hukin-2015-0012.

38. Kaplanová T., Přidalová M., Zbořilová V. Adiposity and physical activity in physically active and inactive elderly women at the university of third age in Palacký University Olomouc. JPES 2018; 18(2): 792-799, doi: 10.7752/jpes.2018.02117.

39. Klimešová I., Wittmannová J., Kováčová L. Hydration status in Czech elderly adults: Gender and physical activity differences. Acta Gymnica 2018; 48(4): 167-174, doi: 10.5507/ag.2018.023.

40. Pereira da Silva A., Matos A., Valente A., Gil A., Alonso J., Ribeiro R. et al. Body composition assessment and nutritional status evaluation in men and women Portuguese centenarians. J. Nutr. Health Aging 2016; 20(3): 256-266, doi: 10.1007/s12603-015-0566-0.

41. Su Y., Hirayama K., Han T.F., Izutsu M., Yuki M. Sarcopenia Prevalence and Risk Factors among Japanese Community Dwelling Older Adults Living in a Snow-Covered City According to EWGSOP2. J. Clin. Med. 2019; 8(3): 291, doi: 10.3390/jcm8030291.

42. Aglago K.E., Menchawy I.E., Kari K.E., Hamdouchi A.E., Barkat A., Bengueddour R. et al. Development and validation of bioelectrical impedance analysis equations for predicting total body water and fat-free mass in North-African adults. Eur. J. Clin. Nutr. 2013; 67(10): 1081-1086, doi: 10.1038/ejen.2013.125

43. Tewari N., Awad S., Macdonald I.A., Lobo D.N. A comparison of three methods to assess body composition. Nutrition 2018; 47: 1-5, doi: 10.1016/j.nut.2017.09.005. 